\title{
産業廃棄物処理行政の現状と課題
}

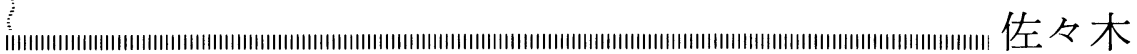

\section{1. 産業廃棄物処理行政の現状}

\section{1 産業廃棄物の排出亡処理処分の状況}

産業廃棄物には, 燃えがら, 污でい等19種類があり, 厚生省調查によれば, 昭和55年度の全国での総排出量 は, およそ 2 億 9000 万トンで, 昭和 50 年度の約 2 億 4 , 000 万トンから 5 年間で約 5,000 万トンの増となってい る.乙の伸び率は, その間の経済成長率を若干下回っ たものとなっている．主な増加の原因は，排水処理に 伴う污でいの増によるものと考えられている（表 1 ).

表 1 産業廃棄物の種類別排出量 (昭和 55 年度, 昭和 50 年度)

\begin{tabular}{|c|c|c|c|c|c|}
\hline & \multicolumn{2}{|c|}{ 今回調查 (55) } & \multicolumn{2}{|c|}{ 前回調查(50) } & \multirow{2}{*}{$\begin{array}{l}5 \text { 年間の } \\
\text { 伸 び率 }\end{array}$} \\
\hline & 千 $\mathrm{t} /$ 年 & $\%$ & 千 $\mathrm{t} /$ 年 & 96 & \\
\hline 燃 え が ら & 1,797 & 0.6 & 1,203 & 0.5 & 49.4 \\
\hline 泥 & (1) 88,190 & 30.2 & (2) 37,660 & 15.9 & 134.2 \\
\hline 油 & 2,419 & 0.8 & 2,289 & 1.0 & 5.7 \\
\hline 酸 & (7) 10,219 & 3.5 & (7) 9,872 & 4.2 & 3.5 \\
\hline 廃 ア ルカ リ & (9) $\quad 6,090$ & 2.1 & (5) 14,435 & 6.1 & A 57.8 \\
\hline 廃プラスチック類 & 2,232 & 0.8 & 1,480 & 0.6 & 50.8 \\
\hline 紙 く ず & 1,624 & 0.6 & 991 & 0.4 & 63.9 \\
\hline 木 木 ず & (8) 6,628 & 2.3 & (9) 7,890 & 3.3 & $\Delta \quad 16.0$ \\
\hline 緎 維 く ず & 101 & 0.0 & 204 & 0.1 & $\Delta \quad 50.5$ \\
\hline 動植物 性 残 椬 & (10) 4,323 & 1.5 & 2,596 & 1.1 & 66.5 \\
\hline ゴ ムくず & 92 & 0.0 & 597 & 0.3 & $\Delta 84.6$ \\
\hline 金 属く ず & (5) 13,111 & 4.5 & (6) 9,985 & 4.2 & 31.3 \\
\hline 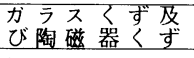 & 2,297 & 0.8 & (10) 2,870 & 1.2 & $\Delta 20.0$ \\
\hline 鉱さ い & (2) 60,561 & 20.7 & (1) 60,950 & 25.8 & $\Delta \quad 0.6$ \\
\hline 建 設 廃 材 & (4) 30,007 & 10.3 & (4) 34,144 & 14.4 & $\mathbf{\Delta \quad 1 2 . 1}$ \\
\hline 動物 ふ ん尿 & (3) 49,629 & 17.0 & (3) 41,184 & 17.4 & 20.5 \\
\hline 動 物 死 体 & 62 & 0.0 & 38 & 0.0 & 63.2 \\
\hline ダ ス & (6) 11,731 & 4.0 & (8) 8,101 & 3.4 & 44.8 \\
\hline 他 & 1,199 & 0.4 & & & \\
\hline 計 & 292,331 & & 236,489 & & 23.6 \\
\hline
\end{tabular}

厚生省水道環境部調べ

* 厚生省水道環境部産業廃棄物対策室・室長補佐 Osamu SASAKI
種類別の排出量で最む多いのは, 污でいで全排出量 の $30.2 \%$ にあたる 8,800 万トン程度となっており，以下， 鉱さい，家畜ふん尿，建設廃材の排出量がこれに続き， それぞれ全排出量の10\%を超えており，てれらの 4 種 類で全排出量の $78.2 \%$ を占める. 次に業種別排出量を みると（図-1), 鉄鋼業, 農業, 鉱業, 建設業の 4 業種 で全排出量の $62.5 \%$ となっており,次いで窒業・土石製 品製造業, 食料品たばて製造業, パルプ・紙・紙加工 品製造業が多くなっている.

すなわち, 昭和 55 年度総排出量 2 億 9,200 万トンのう ち, 中間処理されたあのは 1 億5,400万トン (53\%), 直 接再生利用されたものは 8,800 万トン, 直接最終処分さ れたあのは5,000万トン (17\%) となっている。 また，中

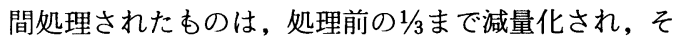
の処理残渣は，再生利用之最終処分に回されている. 最終的には, 全体として総排出量が増加しているにあ かかわらず，再生利用されている量は全体の $43 \%$ （昭 和50年度に比して11\%増）に增加し，最終処分された 量は全体の $23 \%$ (同12\%減)となっている。

昭和 50 年度のデー夕と比較すると, 従来中間処理又 は最終処分されたあのが再生利用に回り, 全体として 最終処分量が減少した。 その結果, 資源化が進み, 環 境に与える負荷が軽減される等, 産業廃棄物処理行政 の着実な進展がうかがえる。

\section{2 産業廃棄物処理業者}

産業廃棄物の処理の形態には, 排出事業者が自ら行

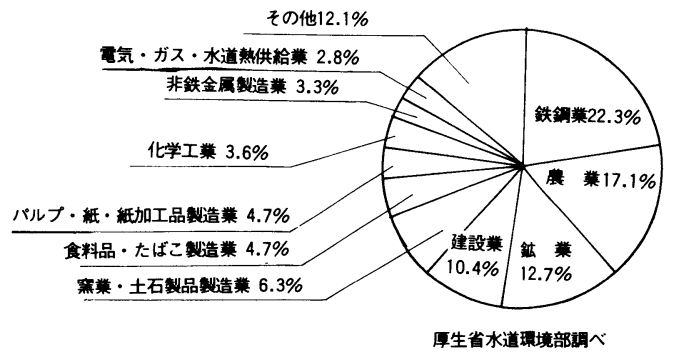

図-1 産業廃棄物の業種別排出割合(昭和55年度) 
う処理, 産業廃棄物処理業者による処理, 都道府県に よる広域的な処理，市町村による一般廃棄物とあわせ ての処理等がある。乙のうち，産業廃棄物処理業者の 許可件数は, 表 2 のとおりである.

表 2 産業廃棄物処理業者許可件数（昭和 58 年 4 月）

\begin{tabular}{|l|r|r|}
\hline & 件 & 数 \\
\hline 割合\%) \\
\hline 収集運搬のみ & 32,106 & 88.9 \\
中間処理のみ & 393 & 1.1 \\
最終処分のみ & 254 & 0.7 \\
収集運搬及び中間処理 & 1,846 & 5.1 \\
収集運搬及び最終処分 & 1,173 & 3.2 \\
中間処理及び最終処分 & 33 & 0.1 \\
収集運搬, 中間処理及び最終処分 & 301 & 0.8 \\
\hline \multicolumn{1}{|c|}{ 計 } & 36,106 & \\
\hline
\end{tabular}

厚生省水道環境部調べ

内訳は，収集運搬業が最む多く，32,106件， $88.9 \%$ を占め, 次いで，収集運搬及び最終処分の 1,173 件, 3.2 \%となっている。

\section{3 産業廃棄物処理施設}

産業廃棄物処理施設の設置状況は, 表 3 のと打りで あり，昭和 58 年 4 月現在で, 総数は9,379，そのうち中 間処理施設は8,093, 最終処分場は1,286となっており, 前年 4 月の 8,890 から増加をみせている.

\section{4 最近の法令等の動き}

（1）廃木材の産業廃棄物指定

廃木材は, 建設工事から発生する一般廃棄物である が，その形状が長大であるてと，量的にも增大してき ていること等により, 市町村による処理では対応しき れなくなったてと等から，抜本的な対策が必要である とされていた。

厚生省では, 昭和53年以降各団体等の要望, 国会で の議論等を踏まえ, 昭和56年11月に厚生省水道環境部 内に設けた廃木材研究会の報告及び右を受けて検討し た生活環境審議会廃棄物処理部会産業廃棄物専門委員 会の「制度の変更に伴う処理体制の混乱を生じないよ う十分な経過措置等を設け, 廃木材を産業廃棄物に指 定することが適当である」との意見を得て，厚生省 は, 廃木材を産業廃棄物として指定するための作業を 開始し，関係省庁等と鋭意調整を行った結果，昭和58 年 4 月26日「廃棄物の処理及び清掃に関する法律施行 令の一部を改正する政令」が公布された。 その改正に おいて廃木材は, 建設業係る木くず（工作物の除去 に伴って生じたもの）として規定され，59年 4 月 1 日 から施行されるとととされた。なお，施行の際現に一
般廃棄物たる廃木材を扱える処理業者については, 昭 和60年 3 月 31 日まで, 廃棄物処理法第14条に基づく許 可が与えられたあのとみなす等の経過措置が付されて いる.

この改正の効果としては, (1)都道府県単位.の処理体 制へと移行するため, 処理の広域化により適正な処理 が図られるようになること，(2)処理の広域化とあいま って, チップ化，燃料化等の原材料としての安定供給 が可能となるため, 再生利用が促進されること, (3)他 の建設廃棄物之同様に産業廃棄物之なるため, 建設廃 棄物の統一的取扱いが可能となるため, 建設廃棄物の 適正処理に資するとと，(4)産業廃棄物になるととによ り, 各種の税制上，金融上の優遇措置を受けられるよ うになるとと,が挙げられる。

（2）有害廃棄物の越境移動に係るOECD決定及び勧告 イタリアのセベンのダイオキシン污染土が国外に搬 出され，行方不明となり，発見後あイタリアが国内へ の搬入を認めなかったという事件を一つの契機として 欧州を中心に，有害廃棄物が国境を越えて移動する際 の通過国，搬入国に対する必要な情報の提供等越境移 動する有害廃棄物の取扱いについてのルールが大きな 問題となった。

このため，OECDを中心とする国際機関において， 有害廃杗物の越境移動のルール化を目指した検討が進 められ，本年 2 月，OECDに扔いて有害廃棄物の越境 移動に関する決定及び勧告が採択された。その内容は， 適正な越境移動が保証されるよう，(1)事業者等関係者

表 3 産業廃棄物処理施設設置状況（昭和58年 4 月）

\begin{tabular}{|c|c|c|c|c|}
\hline \multirow[b]{2}{*}{ 施 設 $の$ 種 類 } & \multirow[b]{2}{*}{ 総数 } & \multicolumn{3}{|c|}{ 設 置 者 } \\
\hline & & 事業者 & $\begin{array}{l}\text { 処理 } \\
\text { 業者 }\end{array}$ & 公共 \\
\hline 污でいの脱水施設 & 4,326 & 3,555 & 200 & 571 \\
\hline 污でいの乾燥施設 & 234 & 146 & 23 & 65 \\
\hline 污でいの焼却施設 & 484 & 365 & 73 & 46 \\
\hline 廃油の油水分離施設 & 364 & 234 & 128 & 2 \\
\hline 廃油の焼却施設 & 444 & 280 & 148 & 16 \\
\hline 廃酸又は廃アルカリの中和施設 & 337 & 232 & 14 & 0 \\
\hline 廃プラスチック類の破砕施設 & 159 & 50 & 105 & 4 \\
\hline 廃プラスチック類の焼却施設 & 1,296 & 922 & 357 & 17 \\
\hline コンクリート固型化施設 & 100 & 46 & 51 & 3 \\
\hline 水銀含有污でいのばい焼施設 & 6 & 2 & 4 & 0 \\
\hline シアンの分解施設 & 343 & 291 & 30 & 22 \\
\hline 小 計 & 8,093 & 6,214 & 1,133 & 746 \\
\hline しゃ断型最終好分場 & 31 & 21 & 10 & 0 \\
\hline 安定型最終処分場 & 479 & 96 & 362 & 21 \\
\hline 管理型最終処分場 & 776 & 286 & 361 & 129 \\
\hline 小 & 1,266 & 403 & 733 & 150 \\
\hline 計 & 9,379 & 6,617 & 1,866 & 896 \\
\hline
\end{tabular}

厚生省水道環境部調べ 
による関係国政府等への情報提供，(2)国内搬入が拒否 された場合の搬出国への再搬入の拒否の禁止のほか, 加盟国による有害廃棄物の越境移動に対する監督等, (3)相手国の許可業者に対する委託等排出事業者の責任 の下での適正処理を原則として定められているが, 今 後, 同機関においてその原則の実施に向け,さらに細 部にわたる検討が行われるとととなった。また，OEC Dの決定は，加盟国を拘束するが，我が国では現在， ての原則に対処する制度がないため, 留保している.

一方, 我が国の場合, 主に産業廃棄物の処理に関し て十分な管理体制を有していない開発途上国が輸出入 の対象国となることも考えられるので，乙れまで昭和 51 年10月25日付け環産第11号厚生省環境衛生局水道環 境部参事官通知に基づき, 事業者等に対し十分な措置 を講じるよう指導してきたが，上記OECDの決定及び 勧告の趣旨を踏まえてその強化・拡充を図るとととし ている.

（3）行政処分の指針の策定

産業廃棄物処理業者に対する許可の取消し等の行政 処分については，乙れまで個別通知及び個別協議によ り取り進めてきたが，法施行後かなりの年月を経過し， 環境保全に対する認識が高いレベルに至っているとと， また, 昨年11月に出された生活環境審議会の答申にお いても, 産業廃棄物処理体制の一層の充実が求められ る旨指摘されていることにかんがみ, 行政処分の指針 を取りまとめた．乙の指針においては，行政処分を悪 質業者に対する行政処分と休眠業者に対する行政処分 に分け, 処分内容決定の際の考慮事項, 手続等を整理 したほか, 虚偽申請に基づく許可の取消しについても 言及している。

（4）トリクロロエチレン等を含む廃棄物の適正処理 昭和59年 8 月23日付けで, トリクロロエチレン等を 含む廃棄物処理に関し，厚生省環境整備課長名による 通知がなされた。こてに至るまでの背景及び内容は以 下のとおりである。

昭和58年 7 月に全国各地の地下水がトリクロロエチ レン等の有機塩素系化合物により污染されているとい う環境庁長官の発表の後, 昭和59年 2 月には, トリク ロロエチレン，テトラクロロエチレン及び $1 ・ 1 ・ 1 卜$ リクロロエタン (以下「トリクロロエチレン等」之略 す.）について水道水の暫定的水質基準が定められる 等諸般の対策等が進められた. その後, 昭和59年 8 月 22日環境庁は水質保全局長名でトリクロロエチレン等 の排出に係る暫定指導指針の設定について通知し, 地
下浸透の防止, 公共用水域への排出時の管理目標を定 め, また, 同日付けの建設省下水道部長名通知により 下水道汇排出される排出水についても管理目標が定め られることとなった。

これらの通知指導等により, 排水処理が強化される 結果, 排水中のトリクロロエチレン等の濃度が低減化 される一方, これらの物質の廃棄物への移行が高まる ことが予想される．また，乙れまで以上にてれらの物 質への関心度が高まるてとによって，今後てれらを含 む廃棄物の発生量の増大が予想される。

本通知の内容は, こうした状況を踏まえ, 下記の事 項に留意するとととしたものである.

(1) トリクロロエチレン等を取り扱う工場及び事業場 から排出される廃棄物の処理状況について, 当該排出 事業者が十分把握するよう指導すること.

(2) トリクロロエチレン等を含む廃棄物の収集運搬保 管を含む）及び処分に当たっては，当該廃棄物の飛散 ・流出防止に留意し，いゃしくあ地下水を污染するこ とのないよう処理基隼を遵守するとと.

(3) トリクロロエチレン等を含む廃裹物の中間処理に 伴って生ずる排水を公共の水域に放流する場合は，当 面, 水質保全局長の管理目標に適合する必要がある.

(4) トリクロロエチレン等を含む廃棄物の最終処分に 伴って生ずる排水を公共の水域に放流する場合は，本 通知によって当面，(3)同様に取り扱う必要があると したてと.

(5) 昭和59年 8 月 23日付けで厚生省生活衛生局指導課 長名でドライクリーニングにおけるテトラクロロエチ レン等の使用管理通知が出されたが，てのような環境 部局から廃棄物の処理方策について協議のあった場合 は，廃棄物が適正に処理されるよう対処されたいとと。 以上の内容は一般廃棄物・産業廃棄物の共通事項之 して通知されている.

\section{2. 産業廃棄物処理行政の今後と基本的方策}

産業廃棄物対策は, 単に産業廃棄物の規制という観 点からのみのアプローチでは限界があり, 国の経済, 産業政策, 社会状況等の総合的観点に立って対処する 必要がある. 産業廃棄物対策は, 廃棄物処理法制定以 来10余年の間に格段の進歩があったが，今後において あ, 適切な産業廃棄物処理行政の実行によって, 一層 の推進を図る必要がある.

厚生省では, 昭和55年11月に生活環境審議会（以下 「審議会」という)に対して,「今後の廃棄物処理行政 
の基本的方策について」と題する諮問を行い, 同審議 会に設けられた産業廃棄物専門委員会において検討が 進められてきたが, 他の専門委員会の報告と併せて同 審議会に打いてさらに検討が加えられた結果, 昭和58 年11月30日に答申「今後の廃棄物処理行政の基本的方 策について」(以下「答申」という) が出された.

\section{1 答申の位置付け}

従来, 厚生省に扔いては, 産業廃棄物処理行政の課 題を(1)不適正処理の是正, (2)資源化再生利用の推進, (3)処分地空間の確保と公共関与のあり方, (4)情報の管 理と活用の 4 項目に整理し，乙㧈らの課題について対 策を推進してきた。今回の答申は, 長期的展望に立っ て，廃萧物処理行政の進むべき基本的方向を示したも のであるが，項目の整理の仕方には若干差異はあるも のの，内容的には，おおむね乙れまでの厚生省の方針 を是認する方向で産業廃棄物処理行政を進めることを 求める内容となっている，以下に执いては，同答申の 中から直接産業廃棄物に係る内容を抜粋して, 同審議 会の答申を紹介することとする.

\section{2 今後の廃棄物処理行政の基本的方策}

答审では，産業廃棄物については,「1）適正処理の 推進」の項を中心狺及されているが，その中で,「廃 棄物の質の多様化が著しく進んだ結果, 排出される廃 棄物の性状に対応した処理基準等の運用が難しい事例 が増加している，乙れについては，環境保全上著しい 支障を及ぼすおそれのある廃棄物を中心として廃棄物 の分類及び処理基準等の適用関係を見直し，てれに基
づく技術的ガイドラインの策定等に努めるべきである. また，最終処分場の閉鎖後の管理の在り方についても 検討に着手すべきである．廃棄物の発生から最終処分 まで一環して廃棄物の適正処理を確保するためには, 長期的ビジョンに基づく計画的な処理の推進が図られ なければならない。……産業廃棄物については, 都 道府県は産業廃棄物処理計画を地域特性に応じた実効 性の高いものとしなければならない。そのためにあ， 大量排出者又は有害廃棄物排出者を中心として, 事業 者においても処理計画を策定するよう努めるべきであ る.さらに, 産業廃棄物の管理の強化及び計画的処理 の推進等を図るうえで信頼性の高い情報の収集及びそ の適切な管理が重要であるととから，情報管理システ ムの整備を図る必要がある，そのため，情報管理シス テムの整備に当たって，国は情報の規格化，システム の互換性の確保等を図るため, システム導入指針の策 定等を行うべきである.」と述べている。 また，同項中 に「(5)産業廃棄物の処理体制の充実として, 以下のと おり記述している。

「産業廃棄物については, 事業者処理の原則が既に確 立され，その原則の下で適正処理の確保のための努力 が重ねられているあのの, 不適正処理事例が多いとと, 事業者等の適正処理意識が必ずしも十分でないとと等 の問題点が指摘されており, 産業廃棄物処理体制の一 層の充実が求められる.

第一に産業廃棄物対策の基本として, 適正処理に関 し，十分な啓発活動が実施されなければならない。そ

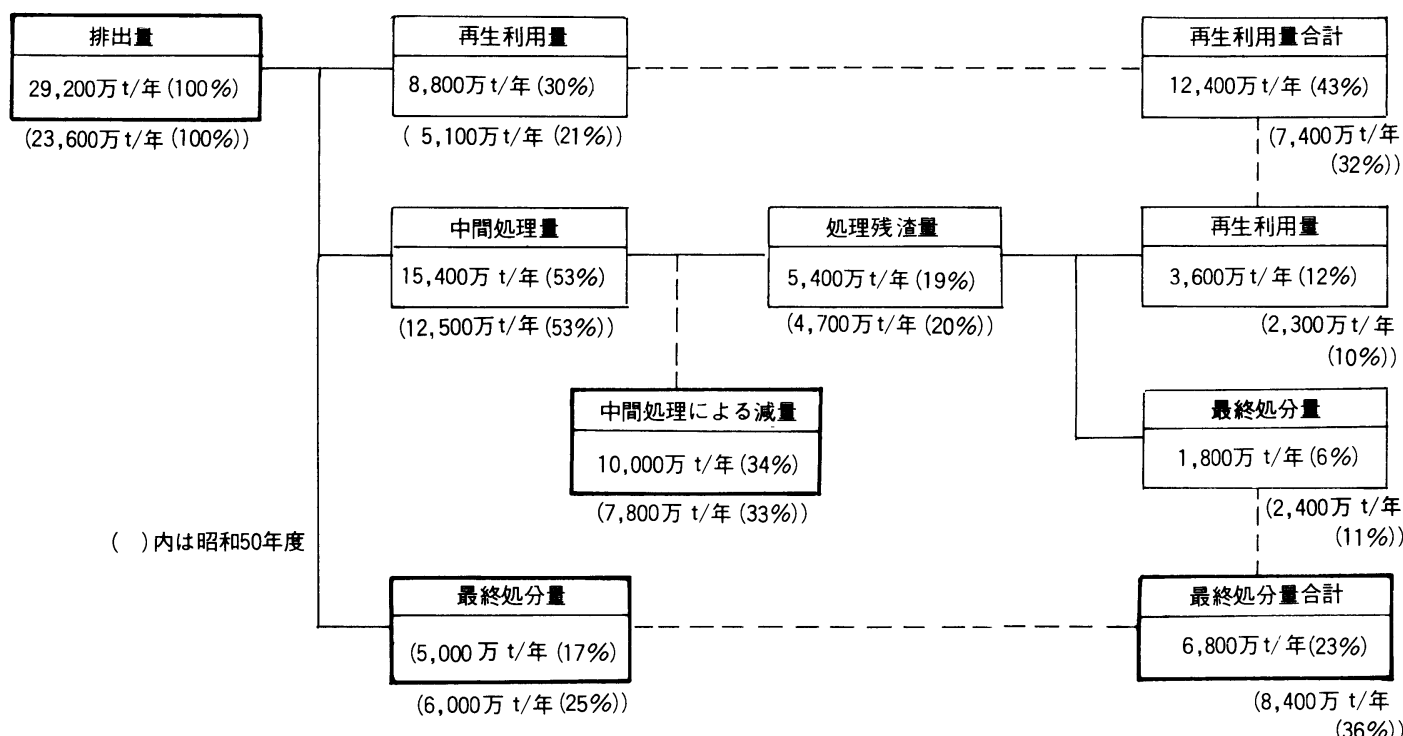

図-2 産業廃棄物の処理フロー(昭和55年度) 
の際，産業廃棄物の適正な妈理は，国民の快適で豊か な生活を確保するうえで不可欠なものであること，事 業活動から直接産業廃棄物が排出される場合はもとよ り, 製造, 加工, 販売等に係る製品等が産業廃棄物に なった場合においても, その適正処理が困難になるて とのないようにしなければならないてと, また, 産業 廃棄物処理に要する経費は事業活動にとって不可欠な コストとして位置付けられなければならないことを強 調する必要がある。

第二に，処理責任を有する事業者における処理体制 の充実を図るため, 事業場を統括管理する者を中心之 した責任体制を明確にし, 共同処理体制を含めた事業 者自らの処理体制の整備が推進されるよう一層の指導 を行うべきである。

また, 産業廃棄物の処理を委託しようとする場合に おいて, 適正な委託を確保するため, 委託内容の文書 化等の指導を行い, 適正処理費用の計上, 委託後の適 正処理の実施の確認を促進する必要がある.

第三に, 産業廃棄物処理業者の産業廃棄物処理に果 たしている役割の大きさにかんがみ，優良な産業廃棄 物処理業者の育成等産業廃棄物処理業界の処理体制の 充実を図る必要がある。そのため産業廃棄物処理業者 の教育指導の徹底, 組織化, 協業化の指導, 許可の在 り方等につき検討すべきである.

また, 産業廃棄物処理業者の適正処理意識の向上, 経済基盤の安定及び技術的能力の向上に努めるべきで ある.さらに，環境保全対策を十分に実施したうえで あなお，万一事故が起てった場合の処理に万全を期す るように，その対策の検討に努めるべきである.

第四に, 産業廃棄物処理施設の設置等を推進するた め, 事業場内の遊休地の利用等により用地の確保を図 るよう指導するととあに, 公共用地のあっせんや土地 利用計画策定時における用地確保について配慮する必 要がある. このほか, 施設整備に対する投資実態の把 握に努め, 金融税制上の措置の拡充強化を図っていく 必要あある.さらに施設設置に係る関係者間の合意形 成ルールの確立を図っていくよう努めるべきである.

一方, 最終処分場の確保や中小企業が排出する産業 廃棄物の処理等民間の努力のみによっては, 十分な対 応ができない場合もあるため, 民間における処理を補 完するものとして必要に応じて, 公共関与による産業 廃棄物処理事業の推進に努めるべきである. その際, 民間処理之の役割分担の明確化及び経営状態の向上に 努めるほか各種の情報提供業務の実施等についても検
討すべきである.

そのほか, 1973年の船舶による污染防止のための国 際条約に関する1978年の議定書（いわゆるマールポロ 条約）への加入に際して国内法が改正されたことに伴 い, 船舶から廃有害液体物質等の海洋への排出が規制 されることとなり, このため陸上における処理が必要 となってきている，したがって，てれら有害液体物質 等の適正な受入処理体制の整備を図っていくべきであ る.」

その外, 答申においては, 資源化有効利用, 技術開 発等各項目において, 資源化有効利用, 技術開発等各 項目において産業廃棄物に関連する内容は含まれてい るが, 紙面の関係上割愛する。

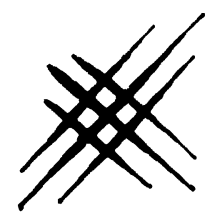

